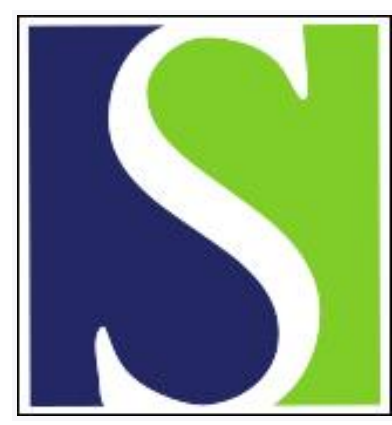

Scand J Work Environ Health 1995;21(3):179-190

https://doi.org/10.5271/sjweh.26

Issue date: Jun 1995

Pooled reanalysis of cancer mortality among five cohorts of workers in wood-related industries

by Demers PA, Boffetta P, Kogevinas M, Blair A, Miller BA, Robinson CF, Roscoe RJ, Winter PD, Colin D, Matos E, Vainio H

The following article refers to this text: 2007;33(5):325-335

Key terms: multiple myeloma; nasal cancer; nasopharyngeal cancer; occupational disease; wood dust

This article in PubMed: www.ncbi.nlm.nih.gov/pubmed/7481605 


\title{
Pooled reanalysis of cancer mortality among five cohorts of workers in wood-related industries
}

\author{
Paul A Demers, PhD, ${ }^{1,2}$ Paolo Boffetta, MD, ${ }^{1}$ Manolis Kogevinas, PhD, ${ }^{1,3}$ Aaron Blair, PhD, ${ }^{4}$ \\ Barry A Miller, MSPH, ${ }^{4}$ Cynthia F Robinson, PhD, ${ }^{5}$ Robert J Roscoe, MSc, ${ }^{5}$ Paul D Winter, MSc, ${ }^{6}$ \\ Didier Colin, MSc, ${ }^{1}$ Elena Matos PhD, ${ }^{1,7}$ Harri Vainio, MD, ${ }^{1,8}$
}

\begin{abstract}
Demers PA, Boffetta P, Kogevinas M, Blair A, Miller BA, Robinson CF, Roscoe RJ, Winter PD, Colin D, Matos E, Vainio $\mathrm{H}$. Pooled reanalysis of cancer mortality among five cohorts of workers in wood-related industries. Scand J Work Environ Health 1995;21:179-90.
\end{abstract}

\begin{abstract}
Objectives To provide more information regarding the risk of cancer associated with wood dust, a pooled reanalysis of data from five cohort studies was performed.

Methods The combined cohort consisted of 28704 persons from five studies: British furniture workers, members of the union representing furniture workers in the United States, two cohorts of plywood workers, and one of wood model makers, among whom 7665 deaths occurred. Pooled analyses were carried out for all of the cohorts combined, the two furniture worker cohorts combined, and the two plywood workers cohorts combined. Results Significant excesses of nasal [observed 11, standardized mortality ratio (SMR) 3.1, 95\% confidence interval (95\% CI) 1.6-5.6] and nasopharyngeal (observed 9, SMR 2.4, 95\% CI 1.1-4.5) cancer were observed. That for nasal cancer appeared to be associated with exposure to wood dust but was based solely on cases from the British furniture worker cohort, while that of nasopharyngeal cancer was observed for furniture and plywood workers and was associated with both high and low probability of wood dust exposure. Some support for an excess risk of multiple myeloma was also observed but was less clearly associated with wood dust exposure. No excesses of lung, larynx, stomach, or colon cancer were found to be associated with any surrogate indicators of wood dust exposure.

Conclusions Workers exposed to wood dust may have an excess risk of nasopharyngeal cancer and multiple myeloma in addition to sinonasal cancer. The limitations of this study would tend to obscure relationships, rather than create false positive findings.
\end{abstract}

Key terms wood dust, multiple myeloma, nasal cancer, nasopharyngeal cancer, occupational diseases.

In October of 1994 wood dust was classified as a human carcinogen by the International Agency for Research on Cancer (1). The evaluation was based on a very high excess risk of sinonasal cancer among exposed workers. This association was first recognized in the 1960s when a very large excess of sinonasal cancer was observed among furniture and other workers exposed to wood dust in the High-Wycombe area of England (2), and many studies since that time have confirmed this finding (37). Some studies have observed excesses of other respiratory, digestive, and hematopoietic system cancers, but the results have been inconsistent $(1,7)$.

The British furniture worker study is the only cohort study which has attempted to classify workers according to level of wood dust exposure $(8,9)$. Many of the cancers suspected of association with wood dust are rela-

1 International Agency for Research on Cancer, Lyon, France.

2 University of British Columbia, Canada.

3 Institut Municipal d'Investigacio Medica, Barcelona, Spain.

4 National Cancer Institute, United States.

5 National Institute for Occupational Safety and Health, United States.

6 Medical Research Council, United Kingdom.

7 Institute of Oncology "Angel H. Roffo," Buenos Aires, Argentina.

8 Institute of Occupational Health, Helsinki, Finland.

Reprint requests to: Dr Paul A Demers, Occupational Hygiene Programme, University of British Columbia, 2206 East Mall, 3rd Floor Vancouver, BC Canada V6T 1 Z3. 
tively rare, and most cohort studies may have lacked sufficient power to determine whether or not an excess risk exists. To provide more information regarding the risk of cancer associated with wood dust, we assembled data from recently completed or updated cohort mortality studies of wood workers for a pooled analysis and developed a classification scheme for wood dust exposure for the pooled cohort based on that used in the British study. Although many types of exposure occur within wood-related industries, the primary purpose of these analyses was to assess the relationship between the risk of cancer and exposure to wood dust. The analyses focused on suspected cancer sites of a priori suspicion as indicated by the results of previous studies.

\section{Subjects and methods}

\section{Participating studies}

The five recently completed or updated cohort mortality studies included in this pooled analysis are listed in table 1 with the entrance criteria used in the original study and the follow-up period available for our analysis. The entrance criteria used for the original studies were also used for our analysis. The follow-up periods for two cohorts, the British (8) and American furniture workers $(10,11)$, have recently been updated, and the extended follow-up periods were used. A brief description of the cohorts is provided below, but further information regarding the design aspects of the studies can be found in reports published earlier $(8,10-15)$.

The cohort of British furniture workers consisted of male workers born prior to 1941 and employed by nine factories in the High-Wycombe area of England prior to 1969. The most recent published follow-up of this cohort was through the end of 1982 (8). Nine additional years of mortality follow-up were performed for our analysis (unpublished). The second cohort consisted of members of the United Furniture Workers of America (UFWA) trade union who began employment between 1946 and 1962
(10). The most recent published follow-up of this cohort was through the end of 1983 (11). Two subcohorts, formed according to the products manufactured at the workplace, were used for the purposes of our analysis (11). The first consisted of workers employed at factories producing wood furniture, and the second was composed of workers employed at factories producing other wood products. Workplaces known to produce nonwood products were excluded.

Two cohorts of plywood workers were included in the pooled analysis. The first consisted of workers employed between 1945 and 1955 and for a minimum of one year by four plywood companies in the northwest United States (US) (12). The cohort was enumerated by investigators from the US National Institute for Occupational Safety and Health (NIOSH), and mortality followup was performed for the years 1946 through 1977. The second cohort of plywood workers was enumerated by investigators from the US National Cancer Institute (NCI) as one of 10 cohorts included in a large study of workers exposed to formaldehyde $(13,14)$. The cohort was comprised of workers employed at any time between 1951 and 1965 by a plywood company in the eastern part of the United States. Mortality follow-up was from 1951 through 1979. The last cohort consisted of workers employed for a minimum of one month in wood model shops within the US automobile manufacturing industry between 1940 and 1980 (15). This cohort was followed for mortality from 1940 through 1984.

\section{Exposure to wood dust}

Industrial hygiene sampling data for the plants under study were only available for the British furniture workers and the US wood model shop workers, but it is likely that exposure to wood dust varied considerably by study. Wood dust exposure levels in the British furniture industry in the High Wycombe area during the 1970 s and 1980 s have been relatively well characterized. Extensive surveys of furniture factories found mean wood dust concentrations of 4.3 (range $0.3-53$ ) $\mathrm{mg} \cdot \mathrm{m}^{-3}$ in 1983

Table 1. Descriptions of cohorts in the pooled reanalysis of wood workers. (US = United States)

\begin{tabular}{|c|c|c|c|}
\hline Cohort description & Entrance criteria & Follow-up & Reference \\
\hline British furniture workers & $\begin{array}{l}\text { First employed before } 1969, \text { no minimum } \\
\text { employment, born before } 1941\end{array}$ & $1941-1991$ & Acheson et al 1984 (8) \\
\hline $\begin{array}{l}\text { Members of the United Furniture } \\
\text { Workers of America trade union }\end{array}$ & $\begin{array}{l}\text { First employed } 1946-62 \text {, no minimum } \\
\text { employment }\end{array}$ & $1946-1983$ & $\begin{array}{l}\text { Miller et al } 1989(10) \\
\text { Miller et al } 1994(11)\end{array}$ \\
\hline US plywood workers & $\begin{array}{l}\text { Employed between } 1945-1955 \\
\text { minimum of } 1 \text { year }\end{array}$ & $1946-1977$ & Robinson et al 1990 (12) \\
\hline US plywood workers & $\begin{array}{l}\text { Employed between } 1951-1965, \text { no minimum } \\
\text { employment }\end{array}$ & $1951-1979$ & $\begin{array}{l}\text { Blair et al } 1990(13) \\
\text { Blair et al } 1986(14)\end{array}$ \\
\hline Wood model shop & $\begin{array}{l}\text { Employed between } 1940-1980, \text { minimum } \\
\text { of } 1 \text { month }\end{array}$ & $1940-1984$ & Roscoe et al $1992(15)$ \\
\hline
\end{tabular}


and 8.5 (range $2.0-32$ ) $\mathrm{mg} \cdot \mathrm{m}^{-3}$ in 1976 and 1977 (16). The authors noted that mainly beech, ash, and elm were used for making tables and chairs while elm, ash, veneered chipboard, and fiberboard were used for cabinets and similar products. Hounam \& Williams (17) also reported personal sampling results for total wood dust for five furniture making factories in the High Wycombe area for 1972 and observed mean exposures of 5.9 (range $1.0-26) \mathrm{mg} \cdot \mathrm{m}^{-3}$. Unfortunately, no results are available for earlier periods, although it is suspected that the exposures could have been much higher.

Wood dust exposure levels in the US furniture industry have been less well characterized. Whitehead et al (18) reported area sampling results for both hardwood (range $0.1-11.4 \mathrm{mg} \cdot \mathrm{m}^{-3}$ ) and softwood (range 0.2 $14.4 \mathrm{mg} \cdot \mathrm{m}^{-3}$ ) furniture manufacturing. These were area samples and thus were not directly comparable to the British results based on personal sampling. Higher exposures have been observed in small shops in the United States, but it is unclear how representative these sampling results are (19). As was the case with the British furniture industry, no industrial hygiene sampling results prior to 1970 were available.

Wood dust exposure potentially occurs during several points in the production of plywood. The highest exposures occur during the sanding, machining, and sawing necessary to finish plywood after the plys (or veneers) have been glued and pressed. Other areas where exposure can occur at lower concentrations are where raw logs are converted into veneer and cut to size. Relatively few data have been collected on exposure to wood dust in US plywood plants. Whitehead et al (18) reported area sampling results for a hardwood plywood manufacturing operation (range $0.1-3.3 \mathrm{mg} \cdot \mathrm{m}^{-3}$ ). Most operations had relatively low levels with the exception of machining, sanding, and sawing operations. Edwards et al (20) reported the results of four personal samples taken in a softwood (fir or cedar) plywood plant in Washington state as part of a NIOSH health hazard evaluation. The mean concentration of wood dust was $0.6(0.3-1.3)$ $\mathrm{mg} \cdot \mathrm{m}^{-3}$, but the operations evaluated were not specified. The plants included in the NIOSH study of plywood workers principally used softwoods (primarily Douglas fir), while the plant in the east, studied by the NCI, reportedly used hardwoods.

Pattern and model making is a highly skilled trade responsible for the production of prototypes, models, and patterns for mass production industries. However, pattern and model making is not a mass production operation, each piece is made individually starting from blueprints and ending with a finished product that must often meet very close tolerances. The materials used include a variety of hard, soft, tropical, and laminated woods, as well as various plastics, resins, and metals. Soft woods are often used for experimental models, while, for models that need to have more exact and stable dimensions, harder and laminated woods are used. An industrial hygiene survey was conducted at one of the plants studied by Roscoe and his colleagues, and the mean for the 58 wood dust samples was 1.0 (range $0.1-13.9$ ) $\mathrm{mg} \cdot \mathrm{m}^{-3}$ $(15,21)$. The average amount of respirable dust was approximately $43 \%(<10 \mu \mathrm{m})$.

It is likely that the exposure levels in this analysis have changed among the cohorts over time. The increasing mechanization and efficiency of wood-working tools have generally increased the level of dust generated, while the increased use of local exhaust ventilation and respiratory protection have decreased the dust levels. In general, exposures in most industrialized countries are likely to have decreased significantly in the last 20 years due to the increasing knowledge of the hazards of wood dust and the regulatory response to that knowledge. Chemicals used in the wood-related industries vary by type of product and are also likely to have changed over time.

\section{Classification of exposure}

The cohorts included in the pooled analysis differed in the amount and detail of data collected exposure. The study of British furniture workers collected job titles for the single "dustiest" job held, which, in most cases, was also the longest job held. The jobs were classified as to dust exposure according to a nine-point relative scale (8). Employment dates were also collected but, unfortunately, the work history follow-up ceased on this cohort after 1968 (while mortality follow-up was continued through 1991). The study of members of the UFWA collected first date of employment and the major product(s) manufactured at the workplace available for all cohort members. In addition, the title of the job at the date of hire was available for $75 \%$ of the cohort. Both studies of plywood workers collected information on all jobs held at the factories under study, but the coding of this data varied. The NIOSH plywood study classified jobs into seven work areas differentiated according to qualitative exposure, while the NCI plywood study collected job and work area titles used in the factory. The workers employed in wood model shops in the auto industry had first date of employment in a wood model shop but last date of employment in the auto company.

In order to analyze the risk of cancer associated with wood dust exposure, a special classification scheme was developed incorporating the exposure information available for each study. Wood dust exposure categories were chosen according to the exposure categories used in the British furniture and the NIOSH plywood worker studies and the data available from the other studies. Three categories were defined according to the assumed probability of exposure: possibly exposed, probably exposed, and 
definitely exposed. British furniture workers were placed in categories according to the "dust" classification in the original study: less dusty (categories $1-3$ ), dusty (categories 4-6), and very dusty (categories 7-9) (8). For the cohorts based upon the membership of the UFWA, job titles were used to place workers in categories similar to those in the British study. The plywood workers were categorized using the department codes and qualitative exposure information from the NIOSH study and department and job titles from the NCI study. Workers in plywood finishing operations were placed in the category with the highest probability of wood dust exposure, workers employed in processing fresh logs and making veneer were classified into the middle category, and all others were classified as possibly exposed. All wood model shop workers were placed in the probable category because no information on individual exposure was available. A complete description of the wood dust classification scheme is available in an IARC technical report (40).

Full work history information was available for the two plywood worker cohorts, and therefore analyses could be made by duration of total employment and employment in jobs with potential wood dust exposure. One element that all cohorts in the pooled analysis had in common was year of first employment. This information was used to classify workers according to calendar period of employment as an indicator of potential exposure.

\section{Analysis}

Analyses for standardized mortality ratio (SMR) were carried out on a VAX mainframe computer using the person-years program with standardization by five-year age and calendar periods $(22,23)$. Ninety-five percent confidence intervals $(95 \% \mathrm{CI})$ were calculated on the assumption of a Poisson distribution. Reference rates for US mortality specific for gender and race (white-nonwhite) were supplied by NIOSH for use with the US studies (24). Mortality rates for England and Wales, obtained from the World Health Organization mortality data bank, were used for the British furniture workers. Parallel analyses were performed for each cohort for cancer sites observed to be in excess in the participating studies and those of a priori interest, based on a review of the literature. The cancer sites chosen were the nose, nasopharynx, larynx, lung, lymphatic and hematopoietic system, colon, and stomach. In addition, the risk of death due to nonmalignant respiratory disease and, more specifically, to bronchitis, emphysema, and asthma were examined. For each of these causes of death, analyses were carried out by the classification of wood dust exposure, decade of first employment, years since first employment, and combinations of these three variables. Analyses by duration of employment were performed for the plywood worker cohorts only because the information on duration of employment was not available for the UFWA study and was incomplete for the British furniture worker study. Lagging of exposure by 5, 10, and 20 -year intervals was used to allow for a latency period (25).

The observed and expected numbers from these parallel analyses were summed for the pooled analysis. In this paper the results are presented for all of the cohorts combined, the two furniture worker cohorts combined, and the two plywood worker cohorts combined. The results of all of the pooled analyses were inspected to determine if the results were due to excesses or deficits from individual studies. In such cases, individual study results were also reported. Gender and race (white-non-

Table 2. Final vital status by participating cohort. (US = United States, UFWF = United Furniture Workers of America, NIOSH = National Institute of Occupational Safety and Health, $\mathrm{NCl}=$ National Cancer Institute)

\begin{tabular}{|c|c|c|c|c|c|}
\hline \multirow[t]{2}{*}{ Cohort description } & \multirow[t]{2}{*}{ Total } & \multicolumn{2}{|c|}{ Deceased } & \multicolumn{2}{|c|}{ Missing } \\
\hline & & $N$ & $\%$ & N & $\%$ \\
\hline \multicolumn{6}{|l|}{ Wood furniture workers } \\
\hline $\begin{array}{l}\text { British (High-Wycombe) } \\
\text { US (members of UFWA) } \\
\text { Total furniture }\end{array}$ & $\begin{aligned} 5106 \\
12158 \\
17264\end{aligned}$ & $\begin{array}{l}2432 \\
2569 \\
5001\end{array}$ & $\begin{array}{l}48 \\
21 \\
29\end{array}$ & $\begin{array}{r}197 \\
872 \\
1069\end{array}$ & $\begin{array}{l}4 \\
7 \\
6\end{array}$ \\
\hline \multicolumn{6}{|l|}{ Plywood workers } \\
\hline $\begin{array}{l}\text { Northwest US (NIOSH) } \\
\text { Eastern US (NCI) } \\
\text { Total plywood }\end{array}$ & $\begin{array}{l}2280 \\
2309 \\
4589\end{array}$ & $\begin{array}{l}569 \\
364 \\
933\end{array}$ & $\begin{array}{l}25 \\
16 \\
20\end{array}$ & $\begin{array}{r}35 \\
105 \\
140\end{array}$ & $\begin{array}{l}2 \\
5 \\
3\end{array}$ \\
\hline \multicolumn{6}{|l|}{ Other wood workers } \\
\hline \multirow{2}{*}{$\begin{array}{l}\text { Automotive wood model shop } \\
\text { Other US wood products } \\
\text { (members of UFWA) }\end{array}$} & 2294 & 706 & 31 & 28 & 1 \\
\hline & 4557 & 1025 & 22 & 352 & 8 \\
\hline Total all wood workers & 28704 & 7665 & 27 & 1589 & 6 \\
\hline
\end{tabular}


white) specific results were also examined to determine if they differed from the results for the full cohort. The results of the parallel analyses of the individual cohorts and the complete results of the pooled analyses are available in an IARC technical report (40).

\section{Results}

The size and vital status at the end of follow-up of each of the cohorts are presented in table 2 . The pooled cohort consisted of 28704 persons, among whom 7665 deaths had occurred. The NIOSH plywood and wood model shop cohorts were composed of white males and the British furniture workers were all men (race unspecified, but assumed to be white). Thus the cohort was primarily male $(92 \%)$ and white (89\%). However, 3165 cohort members were nonwhite and composed $12 \%(\mathrm{~N}=1460)$, $16 \%(\mathrm{~N}=733)$ and $42 \%(\mathrm{~N}=972)$ of the US wood furniture, other wood products, and NCI plywood cohorts, respectively. The cohort also included 2198 women who composed $15 \%(\mathrm{~N}=1778)$ and $9 \%(\mathrm{~N}=420)$ of the US wood furniture and the other wood product cohorts, respectively. Eighty-three women and 53 persons of other and unknown race from the NCI plywood study were excluded because of their small numbers. Other differences in the relation to numbers in published reports were due to the exclusion of three members of the NIOSH plywood worker cohort due to missing birth dates and the deletion of one duplicate record from the British furniture worker cohort which was discovered in the course of extending the follow-up.

Table 3 displays the summary mortality results for all cohorts combined. Overall mortality was significantly less than expected when compared with the general population rates. Statistically significant excesses were observed only for sinonasal and nasopharyngeal cancer. Among the other cancers, a greater number of multiple myeloma deaths was observed than expected, but for all other sites the relative risks observed were less than or close to one, and statistically significant deficits were observed for cancers of the buccal cavity and pharynx, intestines, liver, lung, skin, bladder, and leukemia. The standardized mortality ratios for nonmalignant respiratory disease and bronchitis, emphysema, and asthma, as well as for all other noncancer causes of death, were less than one.

In table 4 the summary results are presented for the furniture and plywood worker cohorts. The standardized mortality ratios observed for most cancers and nonmalignant causes of death were less than or close to one. All 11 nasal cancer deaths and seven of the nine nasopharyngeal cancer deaths occurred among the furniture workers. Two nasopharyngeal cancers occurred among ply-
Table 3. Summary of mortality results of all of the wood worker cohorts combined. $(0=$ observed number of deaths, $\mathrm{E}=$ expected number of deaths, $\mathrm{SMR}=$ standardized mortality ratio, $95 \% \mathrm{Cl}=95 \%$ confidence interval, CNS = central nervous system)

\begin{tabular}{|c|c|c|c|c|}
\hline Cause of death ${ }^{\mathrm{a}}$ & 0 & $\mathrm{E}$ & SMR & $95 \% \mathrm{Cl}$ \\
\hline All cancers $(140-208)$ & 1726 & 2165 & 0.8 & $0.8-0.8$ \\
\hline $\begin{array}{l}\text { Buccal cavity and pharynx } \\
\text { cancer }(140-149)\end{array}$ & 36 & 54.1 & 0.7 & $0.5-0.9$ \\
\hline Pharynx cancer (146-149) & 20 & 24.1 & 0.8 & $0.5-1.3$ \\
\hline Nasopharynx cancer (147) & 9 & 3.8 & 2.4 & $1.1-4.5$ \\
\hline $\begin{array}{l}\text { Esophageal cancer }(150) \\
\text { Stomach cancer }(151) \\
\text { Intestinal cancer }(152,153) \\
\text { Rectal cancer }(154) \\
\text { Biliary passaces and liver }\end{array}$ & $\begin{array}{r}46 \\
138 \\
136 \\
60\end{array}$ & $\begin{array}{c}60.0 \\
153 \\
180 \\
76.6\end{array}$ & $\begin{array}{l}0.8 \\
0.9 \\
0.8 \\
0.8\end{array}$ & $\begin{array}{l}0.6-1.0 \\
0.8-1.1 \\
0.6-0.9 \\
0.6-1.0\end{array}$ \\
\hline cancer $(155,156)$ & 20 & 33.7 & 0.6 & $0.4-0.9$ \\
\hline Pancreatic cancer (157) & 96 & 106.4 & 0.9 & $0.7-1.1$ \\
\hline Sinonasal cancer (160) & 11 & 3.5 & 3.1 & $1.6-5.6$ \\
\hline Larynx cancer (161) & 18 & 27.2 & 0.7 & $0.4-1.0$ \\
\hline Lung cancer (162) & 575 & 721 & 0.8 & $0.7-0.9$ \\
\hline Bone cancer (170) & 9 & 8.4 & 1.1 & $0.5-2.0$ \\
\hline Connective and soft tissue & & & & \\
\hline cancer $(171)$ & 5 & 7.9 & 0.6 & $0.2-1.5$ \\
\hline Skin cancer $(172,173)$ & 14 & 29.5 & 0.5 & $0.3-0.8$ \\
\hline Breast cancer $(174,175)$ & 17 & 30.8 & 0.6 & $0.3-0.9$ \\
\hline Prostate cancer (185) & 137 & 148 & 0.9 & $0.8-1.1$ \\
\hline Bladder cancer (188) & 46 & 71.2 & 0.7 & $0.5-0.9$ \\
\hline Kidney cancer (189) & 34 & 44.8 & 0.8 & $0.5-1.1$ \\
\hline Brain, CNS cancer $(191,192)$ & 44 & 52.1 & 0.8 & $0.6-1.1$ \\
\hline $\begin{array}{l}\text { All lymphatic and hematopoietic } \\
\text { cancers }(200-208)\end{array}$ & 149 & 170 & 0.9 & $0.7-1.0$ \\
\hline Non-Hodgkin's lymphoma & 57 & 530 & 11 & $08-14$ \\
\hline Hodgkin's disease (201) & 12 & 19.2 & 0.6 & $0.3-1.1$ \\
\hline Multiple myeloma (203) & 33 & 25.0 & 1.3 & $0.9-1.9$ \\
\hline Leukemia (204-208) & 47 & 70.3 & 0.7 & $0.5-0.9$ \\
\hline Circulatory disease (390-459) & 3699 & 4918 & 0.8 & $0.7-0.8$ \\
\hline $\begin{array}{l}\text { Ischemic heart disease } \\
(410-414)\end{array}$ & 2535 & 3276 & 0.8 & $0.7-0.8$ \\
\hline Respiratory disease (460-519) & 678 & 837 & 0.8 & $0.8-0.9$ \\
\hline $\begin{array}{l}\text { Bronchitis, asthma, emphysema } \\
(490-493)\end{array}$ & 252 & 297 & 0.9 & $0.8-1.0$ \\
\hline Digestive diseases $(520-579)$ & 308 & 419 & 0.7 & $0.7-0.8$ \\
\hline Cirrhosis of the liver (571) & 130 & 182 & 0.7 & $0.6-0.9$ \\
\hline External causes $(800-999)$ & 550 & 766 & 0.7 & $0.7-0.8$ \\
\hline All causes (001—999) & 7665 & 9983 & 0.8 & $0.8-0.8$ \\
\hline
\end{tabular}

${ }^{a}$ Code of the Internaltional Classification of Diseases, ninth revision, in parentheses.

wood workers. A greater than expected number of deaths from Hodgkin's disease and multiple myeloma were observed among the plywood workers, but the confidence intervals were wide and included one.

Tables 5, 6, and 7 present the stratified results by likelihood of wood dust exposure, decade of first employment, and years since first employment, respectively. Among study subjects identified as having the highest probability of wood dust exposure, the relative risks for both nasopharyngeal and sinonasal cancer were elevated (table 5). The SMR for furniture workers in the highest 
Table 4. Summary of mortality results for the furniture and plywood workers. $(0=$ observed number of deaths, $E=$ expected number of deaths, SMR = standardized mortality ratio, $95 \% \mathrm{CI}=95 \%$ confidence interval, CNS = central nervous system)

\begin{tabular}{|c|c|c|c|c|c|c|c|c|}
\hline \multirow[t]{2}{*}{ Cause of death } & \multicolumn{4}{|c|}{ Furniture workers } & \multicolumn{4}{|c|}{ Plywood workers } \\
\hline & 0 & E & SMR & $95 \% \mathrm{Cl}$ & 0 & E & SMR & $95 \% \mathrm{Cl}$ \\
\hline All cancers & 1199 & 1506 & 0.8 & $0.8-0.8$ & 141 & 194 & 0.7 & $0.6-0.9$ \\
\hline Buccal cavity and pharynx cancer & 21 & 33.2 & 0.6 & $0.4-1.0$ & 7 & 6.8 & 1.0 & $0.4-2.1$ \\
\hline Pharynx cancer & 13 & 14.3 & 0.9 & $0.5-1.6$ & 5 & 3.2 & 1.6 & $0.5-3.7$ \\
\hline Nasopharynx cancer & 7 & 2.4 & 2.9 & $1.2-5.9$ & 2 & 0.4 & 4.6 & $0.6-16.4$ \\
\hline $\begin{array}{l}\text { Esophageal cancer } \\
\text { Stomach cancer } \\
\text { Intestinal cancer } \\
\text { Rectal cancer } \\
\text { Biliary and liver cancer } \\
\text { Pancreatic cancer } \\
\text { Sinonasal cancer } \\
\text { Larynx cancer } \\
\text { Lung cancer } \\
\text { Bone cancer } \\
\text { Connective and soft tissue cancer } \\
\text { Skin cancer } \\
\text { Breast cancer } \\
\text { Prostate cancer } \\
\text { Bladder cancer } \\
\text { Kidney cancer } \\
\text { Brain and CNS cancer } \\
\text { All lymphatic and hematopoietic cancers }\end{array}$ & $\begin{array}{r}32 \\
102 \\
85 \\
48 \\
14 \\
55 \\
11 \\
9 \\
408 \\
7 \\
5 \\
10 \\
16 \\
102 \\
34 \\
22 \\
27 \\
96\end{array}$ & $\begin{array}{c}42.1 \\
116 \\
117 \\
56.4 \\
22.2 \\
70.9 \\
2.5 \\
17.4 \\
520 \\
5.4 \\
5.16 \\
18.5 \\
24.9 \\
100 \\
51.5 \\
29.5 \\
34.5 \\
110\end{array}$ & $\begin{array}{l}0.8 \\
0.9 \\
0.7 \\
0.9 \\
0.6 \\
0.8 \\
4.3 \\
0.5 \\
0.8 \\
1.3 \\
1.0 \\
0.5 \\
0.6 \\
1.0 \\
0.7 \\
0.7 \\
0.8 \\
0.9\end{array}$ & $\begin{array}{l}0.5-1.1 \\
0.7-1.1 \\
0.6-0.9 \\
0.6-1.1 \\
0.4-1.1 \\
0.6-1.0 \\
2.2-7.8 \\
0.2-1.0 \\
0.7-0.9 \\
0.5-2.7 \\
0.3-2.3 \\
0.3-1.0 \\
0.4-1.0 \\
0.8-1.2 \\
0.5-0.9 \\
0.5-1.1 \\
0.5-1.1 \\
0.7-1.1\end{array}$ & $\begin{array}{r}3 \\
5 \\
12 \\
2 \\
4 \\
15 \\
0 \\
2 \\
46 \\
0 \\
0 \\
1 \\
0 \\
5 \\
1 \\
4 \\
7 \\
21\end{array}$ & $\begin{array}{r}5.8 \\
12.2 \\
16.8 \\
6.35 \\
3.4 \\
10.6 \\
0.32 \\
3.1 \\
58.8 \\
1.07 \\
0.8 \\
3.3 \\
0.3 \\
12.5 \\
5.6 \\
4.6 \\
5.8 \\
18.6\end{array}$ & $\begin{array}{l}0.5 \\
0.4 \\
0.7 \\
0.3 \\
1.2 \\
1.4 \\
0.0 \\
0.6 \\
0.8 \\
0.0 \\
0.0 \\
0.3 \\
0.0 \\
0.4 \\
0.2 \\
0.9 \\
1.2 \\
1.1\end{array}$ & $\begin{array}{l}0.1-1.5 \\
0.1-1.0 \\
0.4-1.3 \\
0.0-1.1 \\
0.3-3.0 \\
0.8-2.3 \\
0.0-11.5 \\
0.1-2.3 \\
0.6-1.0 \\
0.0-3.5 \\
0.0-4.6 \\
0.0-1.7 \\
0.0-11.9 \\
0.1-0.9 \\
0.0-1.0 \\
0.2-2.2 \\
0.5-2.5 \\
0.7-1.7\end{array}$ \\
\hline $\begin{array}{l}\text { Non-Hodgkin's lymphoma } \\
\text { Hodgkin's disease } \\
\text { Multiple myeloma } \\
\text { Leukemia }\end{array}$ & $\begin{array}{r}37 \\
8 \\
20 \\
31\end{array}$ & $\begin{array}{l}34.4 \\
12.1 \\
17.4 \\
44.9\end{array}$ & $\begin{array}{l}1.1 \\
0.7 \\
1.2 \\
0.7\end{array}$ & $\begin{array}{l}0.8-1.5 \\
0.3-1.5 \\
0.7-1.8 \\
0.5-1.0\end{array}$ & $\begin{array}{l}7 \\
4 \\
4 \\
6\end{array}$ & $\begin{array}{r}5.56 \\
2.66 \\
2.0 \\
7.8\end{array}$ & $\begin{array}{l}1.3 \\
1.5 \\
2.0 \\
0.8\end{array}$ & $\begin{array}{l}0.5-2.6 \\
0.4-3.9 \\
0.5-5.1 \\
0.3-1.7\end{array}$ \\
\hline Circulatory disease & 2355 & 3188 & 0.7 & $0.7-0.8$ & 446 & 530 & 0.8 & $0.8-0.9$ \\
\hline Ischemic heart disease & 1578 & 2122 & 0.7 & $0.7-0.8$ & 305 & 357 & 0.9 & $0.8-1.0$ \\
\hline Respiratory disease & 529 & 634 & 0.8 & $0.8-0.9$ & 47 & 58.9 & 0.8 & $0.6-1.1$ \\
\hline Bronchitis, asthma, emphysema & 196 & 238 & 0.8 & $0.7-1.0$ & 22 & 18.5 & 1.2 & $0.8-1.8$ \\
\hline Digestive diseases & 198 & 254 & 0.8 & $0.7-0.9$ & 24 & 56.2 & 0.4 & $0.3-0.6$ \\
\hline Cirrhosis of the liver & 78 & 99.2 & 0.8 & $0.6-1.0$ & 8 & 29.1 & 0.3 & $0.1-0.5$ \\
\hline External causes & 293 & 435 & 0.7 & $0.6-0.8$ & 145 & 132 & 1.1 & $0.9-1.3$ \\
\hline All causes & 5001 & 6597 & 0.8 & $0.7-0.8$ & 933 & 1070 & 0.9 & $0.8-0.9$ \\
\hline
\end{tabular}

Table 5. Relative risk of death by category of wood dust exposure for all of the wood workers. $(0=$ observed number of deaths, $E=$ expected number of deaths, $\mathrm{SMR}=$ standardized mortality ratio, $95 \% \mathrm{Cl}=95 \%$ confidence interval)

\begin{tabular}{|c|c|c|c|c|c|c|c|c|c|c|c|c|}
\hline \multirow[t]{2}{*}{ Cause of death } & \multicolumn{4}{|c|}{ Possible exposure } & \multicolumn{4}{|c|}{ Probable exposure } & \multicolumn{4}{|c|}{ Definite exposure } \\
\hline & 0 & $\mathrm{E}$ & SMR & $95 \% \mathrm{Cl}$ & 0 & E & SMR & $95 \% \mathrm{Cl}$ & 0 & $\mathrm{E}$ & SMR & $95 \% \mathrm{Cl}$ \\
\hline All cancers & 565 & 749.7 & 0.8 & $0.7-0.8$ & 490 & 558.8 & 0.9 & $0.8-1.0$ & 512 & 640.5 & 0.8 & $0.7-0.9$ \\
\hline $\begin{array}{l}\text { Nasopharynx cancer } \\
\text { Stomach cancer } \\
\text { Colon cancer } \\
\text { Sinonasal cancer } \\
\text { Larynx cancer } \\
\text { Lung cancer } \\
\text { All lymphatic and hematopoietic }\end{array}$ & $\begin{array}{r}4 \\
46 \\
34 \\
1 \\
4 \\
195\end{array}$ & $\begin{array}{r}1.4 \\
51.2 \\
62.5 \\
1.2 \\
9.4 \\
245\end{array}$ & $\begin{array}{l}2.9 \\
0.9 \\
0.5 \\
0.8 \\
0.4 \\
0.8\end{array}$ & $\begin{array}{l}0.8-7.5 \\
0.7-1.2 \\
0.4-0.8 \\
0.0-4.6 \\
0.1-1.1 \\
0.7-0.9\end{array}$ & $\begin{array}{r}0 \\
43 \\
44 \\
1 \\
8 \\
163\end{array}$ & $\begin{array}{r}0.9 \\
37.7 \\
48.7 \\
0.9 \\
7.4 \\
181\end{array}$ & $\begin{array}{l}0.0 \\
1.1 \\
0.9 \\
1.2 \\
1.1 \\
0.9\end{array}$ & $\begin{array}{l}0.0-3.8 \\
0.8-1.5 \\
0.7-1.2 \\
0.0-6.5 \\
0.5-2.1 \\
0.8-1.1\end{array}$ & $\begin{array}{r}5 \\
41 \\
41 \\
9 \\
6 \\
166\end{array}$ & $\begin{array}{r}0.9 \\
54.2 \\
49.5 \\
1.1 \\
7.4 \\
229\end{array}$ & $\begin{array}{l}5.3 \\
0.8 \\
0.8 \\
8.4 \\
0.8 \\
0.7\end{array}$ & $\begin{array}{l}1.7-12.4 \\
0.5-1.0 \\
0.6-1.6 \\
3.9-16.0 \\
0.3-1.8 \\
0.6-0.9\end{array}$ \\
\hline cancers & 41 & 60.0 & 0.7 & $0.5-0.9$ & 40 & 45.6 & 0.9 & $0.6-1.2$ & 50 & 44.7 & 1.1 & $0.8-1.5$ \\
\hline $\begin{array}{l}\text { Non-Hodgkin's lymphoma } \\
\text { Hodgkin's disease } \\
\text { Multiple myeloma } \\
\text { Leukemia }\end{array}$ & $\begin{array}{r}15 \\
2 \\
9 \\
15\end{array}$ & $\begin{array}{r}18.7 \\
6.9 \\
8.8 \\
24.6\end{array}$ & $\begin{array}{l}0.8 \\
0.3 \\
1.0 \\
0.6\end{array}$ & $\begin{array}{l}0.5-1.3 \\
0.0-1.0 \\
0.5-1.9 \\
0.3-1.0\end{array}$ & $\begin{array}{r}19 \\
3 \\
8 \\
10\end{array}$ & $\begin{array}{r}14.2 \\
4.9 \\
6.31 \\
19.3\end{array}$ & $\begin{array}{l}1.3 \\
0.6 \\
1.3 \\
0.5\end{array}$ & $\begin{array}{l}0.8-2.1 \\
0.1-1.8 \\
0.6-2.5 \\
0.3-1.0\end{array}$ & $\begin{array}{r}17 \\
6 \\
11 \\
16\end{array}$ & $\begin{array}{r}13.6 \\
4.9 \\
7.1 \\
18.5\end{array}$ & $\begin{array}{l}1.3 \\
1.2 \\
1.6 \\
0.9\end{array}$ & $\begin{array}{l}0.7-2.0 \\
0.4-3.2 \\
0.8-2.8 \\
0.5-1.4\end{array}$ \\
\hline Respiratory disease & 236 & 276 & 0.9 & $0.8-1.0$ & 157 & 206 & 0.8 & $0.7-0.9$ & 229 & 296 & 0.8 & $0.7-0.9$ \\
\hline Bronchitis, emphysema and asthma & 97 & 96.2 & 1.0 & $0.8-1.2$ & 53 & 69.3 & 0.8 & $0.6-1.0$ & 86 & 115 & 0.8 & $0.6-0.9$ \\
\hline
\end{tabular}


Table 6. Relative risk of death by calender period of first employment for all of the wood workers. $(0=$ observed number of deaths, $E=$ expected number of deaths, SMR $=$ standardized mortality ratio, $95 \% \mathrm{Cl}=95 \%$ confidence interval)

\begin{tabular}{|c|c|c|c|c|c|c|c|c|c|c|c|c|c|c|c|c|}
\hline \multirow[t]{2}{*}{ Cause of death } & \multicolumn{4}{|c|}{ Prior to 1940} & \multicolumn{4}{|c|}{$1940-1949$} & \multicolumn{4}{|c|}{$1950-1959$} & \multicolumn{4}{|c|}{1960 or later } \\
\hline & 0 & $E$ & SMR & $95 \% \mathrm{Cl}$ & 0 & $E$ & SMR & $95 \% \mathrm{Cl}$ & 0 & $E$ & SMR & $95 \% \mathrm{Cl}$ & 0 & $E$ & SMR & $95 \% \mathrm{Cl}$ \\
\hline All cancers & 354 & 416 & 0.9 & $0.8-1.0$ & 464 & 589 & 0.8 & $0.7-0.9$ & 700 & 905 & 0.8 & $0.7-0.8$ & 208 & 255 & 0.8 & $0.7-0.9$ \\
\hline Nasopharynx cancer & 3 & 0.4 & 7.7 & $1.6-22.5$ & 5 & 0.9 & 5.3 & $1.7-12.3$ & 0 & 1.8 & 0.0 & $0.0-2.0$ & 1 & 0.6 & 1.7 & $0.0-9.3$ \\
\hline Stoma & 35 & 45.2 & 0.8 & $0.5-1.1$ & 33 & 40.5 & 0.8 & -1.1 & 51 & 53.2 & 1.0 & -1.3 & 19 & 14.5 & 1.3 & $0.8-2.1$ \\
\hline Colon & 31 & 30.0 & 1.0 & $0.7-1.5$ & 34 & 52.3 & 0.7 & $0.5-0.9$ & 49 & 77.2 & 0.6 & -0.8 & 22 & 20.5 & 1.1 & $0.7-1.6$ \\
\hline Sinonasal c & 9 & 0.7 & 12.5 & $5.7-23.7$ & 1 & 0.9 & 1.2 & $0.1-6.6$ & 1 & 1.5 & 0.7 & $0.0-3.8$ & 0 & 0.4 & 0.0 & $0.0-8.8$ \\
\hline Laryn & 2 & 4.3 & 0.5 & $0.1-1.7$ & 5 & 7.9 & 0.6 & $0.2-1.5$ & 8 & 11.8 & 0.7 & $0.3-1.3$ & 3 & 3.1 & 1.0 & $0.2-2.8$ \\
\hline $\begin{array}{l}\text { Lung cancer } \\
\text { All lymphatic and }\end{array}$ & 111 & 155 & 0.7 & $0.7-0.9$ & 149 & 185 & 0.8 & $0.7-1.0$ & 252 & 295 & 0.9 & $0.8-1.0$ & 63 & 86.8 & 0.7 & $0.6-0.9$ \\
\hline hematopoietic cancers & 21 & 22.6 & 0.9 & $0.6-1.4$ & 54 & 47.2 & 1.1 & $0.8-1.5$ & 61 & 75.6 & 0.8 & $0.6-1.1$ & 13 & 22.0 & 0.6 & $0.3-1.0$ \\
\hline kin's & & 6.4 & 1.4 & $0.7-2.7$ & 14 & 14.8 & 1.0 & & 26 & 24.5 & 1.1 & & 8 & 7.2 & 1.1 & $0.5-2.2$ \\
\hline Hodgkin's disease & ( & 2.2 & 0.0 & $0.0-1.7$ & 7 & 5.3 & 1.3 & $0.5-2.7$ & 5 & 8.9 & 0.6 & $0.2-1.3$ & 0 & 2.8 & 0.0 & $0.0-1.3$ \\
\hline Mult & & 4.1 & 1.7 & $0.7-3.5$ & 12 & 6.4 & 1.9 & $1.0-3.3$ & 13 & 11.2 & 1.2 & $0.6-2.0$ & 1 & 3.3 & 0.3 & $0.0-1.7$ \\
\hline Leukemia & 5 & 9.9 & 0.5 & $0.2-1.2$ & 21 & 20.6 & 1.0 & $0.6-1.6$ & 17 & 31.0 & 0.6 & $0.3-0.9$ & 4 & 8.7 & 0.5 & $0.1-1.2$ \\
\hline Respiratory disease & 205 & 243 & 0.8 & $0.7-1.0$ & 166 & 208 & 0.8 & $0.7-0.9$ & 249 & 302 & 0.8 & $0.7-0.9$ & 58 & 84.3 & 0.7 & $0.5-0.9$ \\
\hline $\begin{array}{l}\text { Bronchitis, emphy- } \\
\text { sema and asthma }\end{array}$ & 69 & 101 & 0.7 & $0.5-0.9$ & 68 & 70.0 & 1.0 & $0.8-1.2$ & 91 & 98.5 & 0.9 & $0.7-1.1$ & 24 & 27.3 & 0.9 & $0.6-1.3$ \\
\hline
\end{tabular}

Table 7. Relative risk of death by years since first employment for all of the wood workers. $(0=$ observed number of deaths, $\mathrm{E}=$ expected number of deaths, $\mathrm{SMR}=$ standardized mortality ratio, $95 \% \mathrm{Cl}=95 \%$ confidence interval)

\begin{tabular}{|c|c|c|c|c|c|c|c|c|c|c|c|c|c|c|c|c|}
\hline \multirow[t]{2}{*}{ Cause of death } & \multicolumn{4}{|c|}{$<10$ years } & \multicolumn{4}{|c|}{10 to 19 years } & \multicolumn{4}{|c|}{$20-29$ years } & \multicolumn{4}{|c|}{$\geq$ years } \\
\hline & 0 & $E$ & SMR & $95 \% \mathrm{Cl}$ & 0 & E & SMR & $95 \% \mathrm{Cl}$ & 0 & $E$ & SMR & $95 \% \mathrm{Cl}$ & 0 & $E$ & SMR & $95 \% \mathrm{Cl}$ \\
\hline ill cancers & 153 & 278 & 0.6 & $0.5-0.7$ & 413 & 564 & 0.7 & $0.7-0.8$ & 592 & 671 & 0.9 & $0.8-1.0$ & 568 & 653 & 0.9 & $0.8-0.9$ \\
\hline Nasopharynx cancer & 0 & 0.4 & 0.0 & $0.0-9.7$ & 2 & 1.2 & 1.6 & $0.2-5.9$ & 0 & 1.4 & 0.0 & $0.0-2.7$ & 7 & 0.8 & 8.9 & $3.6-18.3$ \\
\hline Stom & 27 & 23.6 & 1.1 & $1.8-1.7$ & 28 & 36.8 & 0.8 & $0.5-1.1$ & 33 & 37.3 & 0.9 & $0.6-1.2$ & 50 & 55.7 & 0.9 & $0.7-1.2$ \\
\hline Colon & 9 & 22.1 & 0.4 & $.2-0.8$ & 33 & 48.0 & 0.7 & $0.5-1.0$ & 53 & 60.0 & 0.9 & $0.7-1.2$ & 41 & 50.3 & 0.8 & $0.6-1.1$ \\
\hline Sinonasal cancer & 0 & 0.3 & 0.0 & $0.0-10.9$ & 0 & 1.0 & 0.0 & $0.0-3.7$ & 3 & 1.2 & 2.6 & $0.5-7.6$ & 8 & 1.1 & 7.6 & $3.3-15.0$ \\
\hline Larynx cancer & 0 & 3.8 & 0.0 & $0.0-1.0$ & 8 & 7.8 & 1.0 & $0.4-2.0$ & 7 & 8.7 & 0.8 & $0.3-1.7$ & 3 & 6.9 & 0.4 & $0.1-1.3$ \\
\hline Lung cancer & 37 & 74.9 & 0.5 & $0.4-0.7$ & 138 & 178 & 0.8 & $0.7-0.9$ & 202 & 228 & 0.9 & $0.8-1.0$ & 198 & 240 & 0.8 & $0.7-1.0$ \\
\hline hematopoietic cancers & 13 & 27.8 & 0.5 & $0.3-0.8$ & 30 & 48.2 & 0.6 & $0.4-0.9$ & 71 & 52.1 & 1.4 & $1.1-1.7$ & 35 & 39.2 & 0.9 & $0.6-1.2$ \\
\hline $\begin{array}{l}\text { Non } \\
\text { lymp }\end{array}$ & 7 & 7.7 & 0.9 & & 11 & 15.4 & 0.7 & $0.4-1.3$ & 25 & 17.4 & 1.4 & $0.9-2.1$ & 14 & 12.5 & 1.1 & $0.6-1.9$ \\
\hline in's disease & 1 & 6.2 & 0.2 & $0.0-0.9$ & 4 & 6.5 & 0.6 & $0.2-1.6$ & 4 & 4.0 & 1.0 & $0.3-2.6$ & 3 & 2.4 & 1.3 & $0.3-3.7$ \\
\hline nyeloma & 0 & 1.6 & 0.0 & $0.0-2.4$ & 7 & 6.2 & 1.1 & $0.5-2.3$ & 17 & 9.2 & 1.9 & $1.1-3.0$ & 9 & 8.0 & 1.1 & $0.5-2.1$ \\
\hline Leukemia & 5 & 12.5 & 0.4 & $0.1-0.9$ & 8 & 20.1 & 0.4 & $0.2-0.8$ & 25 & 21.5 & 1.2 & $0.8-1.7$ & 9 & 16.3 & 0.6 & $0.3-1.1$ \\
\hline Respiratory disease & 41 & 88.9 & 0.5 & $0.3-0.6$ & 132 & 186 & 0.7 & $0.6-0.8$ & 211 & 231 & 0.9 & $0.8-1.1$ & 294 & 331 & 0.9 & $0.8-1.0$ \\
\hline $\begin{array}{l}\text { Bronchitis, emphy- } \\
\text { sema and asthma }\end{array}$ & 20 & 33.0 & 0.6 & $0.4-0.9$ & 55 & 70.6 & 0.8 & $0.6-1.0$ & 79 & 73.2 & 1.1 & $0.9-1.4$ & 98 & 121 & 0.8 & $0.7-1.0$ \\
\hline
\end{tabular}

wood dust exposure category was 9.9 (95\% CI 4.518.8). The risk of multiple myeloma also increased with the probability of assumed exposure to wood dust. No other trends with probability of exposure were apparent.

The SMR values for sinonasal cancer were greatest among workers first employed prior to 1940 (table 6). For furniture workers first employed before 1940 the SMR was 13.4 (95\% CI 6.1-25.5). The SMR values for workers employed prior to 1950 were highly elevated for nasopharyngeal cancer and also appeared to be elevated for multiple myeloma. No other trends with time period of first employment were apparent. In the analysis by years since first employment, the SMR values were highest for sinonasal cancer and nasopharyngeal cancer for the workers at least 30 years after first employment, while the SMR for multiple myeloma was highest for the workers 20 to 29 years after first employment (table 7).

Table 8 summarizes the stratified analyses of nasopharyngeal cancer and multiple myeloma among the furniture and plywood workers separately. For the furniture workers, the pattern was similar to that of sinonasal 
Table 8. Relative risk of nasopharyngeal cancer and multiple myeloma among furniture and plywood workers. $(0=0$ bserved number of cases, $E=$ expected number of cases, $S M R=$ standardized mortality ratio, $95 \% \mathrm{Cl}=95 \%$ confidence interval)

\begin{tabular}{|c|c|c|c|c|c|c|c|c|}
\hline & \multicolumn{4}{|c|}{ Furniture workers } & \multicolumn{4}{|c|}{ Plywood workers } \\
\hline & 0 & E & SMR & $95 \% \mathrm{Cl}$ & 0 & E & SMR & $95 \% \mathrm{Cl}$ \\
\hline \multicolumn{9}{|l|}{ Nasopharyngeal cancer } \\
\hline \multicolumn{9}{|l|}{ Wood dust category } \\
\hline $\begin{array}{l}\text { Possible exposure } \\
\text { Probable exposure } \\
\text { Definite exposure }\end{array}$ & $\begin{array}{l}2 \\
0 \\
5\end{array}$ & $\begin{array}{l}0.9 \\
0.4 \\
0.7\end{array}$ & $\begin{array}{l}2.2 \\
0.0 \\
7.3\end{array}$ & $\begin{array}{l}0.3-7.8 \\
0.0-8.6 \\
2.4-16.9\end{array}$ & $\begin{array}{l}2 \\
0 \\
0\end{array}$ & $\begin{array}{l}0.2 \\
0.1 \\
0.1\end{array}$ & $\begin{array}{r}11.8 \\
0.0 \\
0.0\end{array}$ & $\begin{array}{l}1.4-42.5 \\
0.0-33.5 \\
0.0-28.4\end{array}$ \\
\hline \multicolumn{9}{|c|}{ Time of first employment } \\
\hline $\begin{array}{l}\text { Prior to } 1940 \\
1940-1949 \\
1950-1959 \\
1960 \text { or later }\end{array}$ & $\begin{array}{l}3 \\
4 \\
0 \\
0\end{array}$ & $\begin{array}{l}0.4 \\
0.5 \\
1.2 \\
0.4\end{array}$ & $\begin{array}{l}8.6 \\
7.7 \\
0.0 \\
0.0\end{array}$ & $\begin{array}{l}1.8-25.1 \\
2.1-19.7 \\
0.0-3.1 \\
0.0-0.9\end{array}$ & $\begin{array}{l}0 \\
1 \\
0 \\
1\end{array}$ & $\begin{array}{l}0.0 \\
0.2 \\
0.2 \\
0.0\end{array}$ & $\begin{array}{r}0.0 \\
5.0 \\
0.0 \\
25.0\end{array}$ & $\begin{array}{l}0.0-99.9 \\
0.1-27.9 \\
0.0-20.5 \\
0.6-99.9\end{array}$ \\
\hline \multicolumn{9}{|c|}{ Time since first employment } \\
\hline $\begin{array}{l}<10 \text { years } \\
10-19 \text { years } \\
20-29 \text { years } \\
\geq 30 \text { years }\end{array}$ & $\begin{array}{l}0 \\
0 \\
0 \\
7\end{array}$ & $\begin{array}{l}0.2 \\
0.7 \\
0.8 \\
0.7\end{array}$ & $\begin{array}{r}0.0 \\
0.0 \\
0.0 \\
10.8\end{array}$ & $\begin{array}{l}0.0-15.4 \\
0.0-5.0 \\
0.0-4.5 \\
4.3-22.2\end{array}$ & $\begin{array}{l}0 \\
2 \\
0 \\
0\end{array}$ & $\begin{array}{l}0.0 \\
0.2 \\
0.2 \\
0.0\end{array}$ & $\begin{array}{r}0.0 \\
13.3 \\
0.0 \\
0.0\end{array}$ & $\begin{array}{l}0.0-99.9 \\
1.6-48.2 \\
0.0-16.8 \\
0.0-99.9\end{array}$ \\
\hline \multicolumn{9}{|l|}{ Multiple myeloma } \\
\hline \multicolumn{9}{|l|}{ Wood dust category } \\
\hline $\begin{array}{l}\text { Possible exposure } \\
\text { Probable exposure } \\
\text { Definite exposure }\end{array}$ & $\begin{array}{l}5 \\
4 \\
5\end{array}$ & $\begin{array}{l}6.4 \\
3.3 \\
0.7\end{array}$ & $\begin{array}{l}0.8 \\
1.2 \\
1.2\end{array}$ & $\begin{array}{l}0.3-1.8 \\
0.3-3.1 \\
0.5-2.5\end{array}$ & $\begin{array}{l}3 \\
1 \\
0\end{array}$ & $\begin{array}{l}0.9 \\
0.5 \\
0.5\end{array}$ & $\begin{array}{l}3.5 \\
1.9 \\
0.0\end{array}$ & $\begin{array}{l}0.7-10.1 \\
0.1-10.3 \\
0.0-6.8\end{array}$ \\
\hline \multicolumn{9}{|c|}{ Time of first employment } \\
\hline $\begin{array}{l}\text { Prior to } 1940 \\
1940-1949 \\
1950-1959 \\
1960 \text { or later }\end{array}$ & $\begin{array}{l}6 \\
5 \\
9 \\
0\end{array}$ & $\begin{array}{l}3.7 \\
3.9 \\
7.6 \\
2.2\end{array}$ & $\begin{array}{l}1.6 \\
1.3 \\
1.2 \\
0.0\end{array}$ & $\begin{array}{l}0.6-3.6 \\
0.4-3.0 \\
0.5-2.2 \\
0.0-1.7\end{array}$ & $\begin{array}{l}0 \\
4 \\
0 \\
0\end{array}$ & $\begin{array}{l}0.1 \\
1.2 \\
0.7 \\
0.1\end{array}$ & $\begin{array}{l}0.0 \\
3.5 \\
0.0 \\
0.0\end{array}$ & $\begin{array}{l}0.0-92.2 \\
1.0-8.9 \\
0.0-5.9 \\
0.0-41.0\end{array}$ \\
\hline \multicolumn{9}{|c|}{ Time since first employment } \\
\hline $\begin{array}{l}<10 \text { years } \\
10-19 \text { years } \\
20-29 \text { years } \\
\geq 30 \text { years }\end{array}$ & $\begin{array}{r}0 \\
2 \\
10 \\
8\end{array}$ & $\begin{array}{l}1.1 \\
3.9 \\
5.8 \\
6.7\end{array}$ & $\begin{array}{l}0.0 \\
0.5 \\
1.7 \\
1.2\end{array}$ & $\begin{array}{l}0.0-3.5 \\
0.1-1.8 \\
0.8-3.2 \\
0.5-2.4\end{array}$ & $\begin{array}{l}0 \\
1 \\
2 \\
1\end{array}$ & $\begin{array}{l}0.1 \\
0.5 \\
1.2 \\
0.3\end{array}$ & $\begin{array}{l}0.0 \\
1.9 \\
1.7 \\
3.5\end{array}$ & $\begin{array}{l}0.0-61.5 \\
0.1-10.3 \\
0.2-6.3 \\
0.1-19.2\end{array}$ \\
\hline
\end{tabular}

cancer with the highest risk observed for persons with the highest probability of wood dust exposure, those employed prior to 1940 , and for persons at least 30 years after first employment. However, nasopharyngeal cancers also occurred in two furniture workers and two plywood workers who were not known to have been employed in operations exposed to wood dust. The trends for multiple myeloma with probability of exposure, years since first exposure, and decade of first exposure among the full pooled cohort were also apparent among the pooled furniture workers and also, although based on small numbers, among the plywood workers.

Analyses were also performed with stratification by two-way combinations of probability of exposure, years since first exposure, and decade of first exposure. Eight sinonasal cancers occurred among furniture workers employed in the highest wood dust category prior to 1940 (SMR 18.6, 95\% CI 8.0-36.6). Five nasopharyngeal cancers occurred among furniture workers employed in the highest wood-dust category prior to 1950 (SMR 13.9, 95\% CI 4.4-32.4). In the two-dimensional analysis no new associations appeared that were not readily apparent in tables 5 through 8 . There was no evidence of excess risks of lung, laryngeal, colon, or stomach cancer among the entire pooled cohort, or the pooled furniture or plywood workers alone, when SMR values were examined in relation to the probability of wood-dust exposure, time period of first employment, years since first employment, or combinations of these parameters.

The results of the analyses of plywood workers by total duration of employment and duration of employment in jobs exposed to wood dust (probable or definite) are presented in table 9 for the lymphatic and hematopoietic cancers. All of the exposures were lagged by five years, a latency period thus being allowed for. The risk of death due to all lymphatic and hematopoietic neoplasms was elevated among the workers employed for more than 10 years in any job and for those employed for 10 years or more in wood-exposed jobs. The excess of Hodgkin's disease occurred among the workers employed in wood-exposed jobs while multiple myeloma was elevated among the workers employed 10 or more 
Table 9. Relative risk of death by duration of employment for the plywood workers. ( $0=$ observed number of deaths, $E=$ expected number of deaths, SMR = standardized mortality ratio, $95 \% \mathrm{CI}=95 \%$ confidence interval)

\begin{tabular}{|c|c|c|c|c|c|c|c|c|c|c|c|c|c|c|c|c|}
\hline & \multicolumn{16}{|c|}{ Cause of death } \\
\hline & \multicolumn{4}{|c|}{ Hodgkin's disease } & \multicolumn{4}{|c|}{ Multiple myeloma } & \multicolumn{4}{|c|}{ Non-Hodgkin's Iymphoma } & \multicolumn{4}{|c|}{ Leukemia } \\
\hline & 0 & $E$ & SMR & $95 \% \mathrm{Cl}$ & 0 & $E$ & SMR & $95 \% \mathrm{Cl}$ & 0 & $\mathrm{E}$ & SMR & $95 \% \mathrm{Cl}$ & 0 & $E$ & SMR & $95 \% \mathrm{Cl}$ \\
\hline \multicolumn{17}{|c|}{$\begin{array}{l}\text { Duration of total } \\
\text { employment }\end{array}$} \\
\hline $\begin{array}{l}<5 \text { years } \\
5 \text { to } 9 \text { years } \\
\geq 10 \text { years }\end{array}$ & $\begin{array}{l}0 \\
0 \\
4\end{array}$ & $\begin{array}{l}1.5 \\
0.6 \\
0.7\end{array}$ & $\begin{array}{l}0.0 \\
0.0 \\
6.0\end{array}$ & $\begin{array}{l}0.0-2.5 \\
0.0-7.2 \\
1.6-15.3\end{array}$ & $\begin{array}{l}0 \\
0 \\
4\end{array}$ & $\begin{array}{l}0.6 \\
0.3 \\
1.1\end{array}$ & $\begin{array}{l}0.0 \\
0.0 \\
3.8\end{array}$ & $\begin{array}{l}0.0-6.1 \\
0.0-11.2 \\
1.0-9.7\end{array}$ & $\begin{array}{l}3 \\
1 \\
3\end{array}$ & $\begin{array}{l}2.2 \\
1.1 \\
2.3\end{array}$ & $\begin{array}{l}1.4 \\
0.9 \\
1.3\end{array}$ & $\begin{array}{l}0.3-4.1 \\
0.0-5.2 \\
0.3-3.8\end{array}$ & $\begin{array}{l}1 \\
1 \\
4\end{array}$ & $\begin{array}{l}3.2 \\
1.5 \\
3.1\end{array}$ & $\begin{array}{l}0.3 \\
0.7 \\
1.3\end{array}$ & $\begin{array}{l}0.0-1.8 \\
0.0-3.7 \\
0.4-3.3\end{array}$ \\
\hline \multicolumn{17}{|c|}{$\begin{array}{l}\text { Duration of employment } \\
\text { in jobs exposed } \\
\text { to wood dust }{ }^{\mathrm{a}}\end{array}$} \\
\hline $\begin{array}{l}<1 \text { year } \\
1 \text { to } 4 \text { years } \\
5 \text { to } 9 \text { years } \\
\geq 10 \text { years }\end{array}$ & $\begin{array}{l}0 \\
0 \\
0 \\
4\end{array}$ & $\begin{array}{l}1.6 \\
0.5 \\
0.8 \\
0.0\end{array}$ & $\begin{array}{c}0.0 \\
0.0 \\
0.0 \\
10.0\end{array}$ & $\begin{array}{l}0.0-2.3 \\
0.0-7.3 \\
0.0-4.6 \\
4.8-18.4\end{array}$ & $\begin{array}{l}3 \\
0 \\
0 \\
1\end{array}$ & $\begin{array}{l}1.0 \\
0.3 \\
0.2 \\
0.6\end{array}$ & $\begin{array}{l}3.1 \\
0.0 \\
0.0 \\
1.7\end{array}$ & $\begin{array}{l}0.6-8.9 \\
0.0-12.2 \\
0.0-18.3 \\
0.0-9.4\end{array}$ & $\begin{array}{l}4 \\
0 \\
1 \\
2\end{array}$ & $\begin{array}{l}2.8 \\
0.8 \\
0.6 \\
1.3\end{array}$ & $\begin{array}{l}1.4 \\
0.0 \\
1.6 \\
1.5\end{array}$ & $\begin{array}{l}0.4-3.6 \\
0.0-4.6 \\
0.0-9.1 \\
0.2-5.6\end{array}$ & $\begin{array}{l}3 \\
0 \\
1 \\
2\end{array}$ & $\begin{array}{l}4.3 \\
1.1 \\
0.8 \\
1.6\end{array}$ & $\begin{array}{l}0.7 \\
0.0 \\
1.3 \\
1.3\end{array}$ & $\begin{array}{l}0.1-2.0 \\
0.0-3.3 \\
0.0-7.1 \\
0.2-4.5\end{array}$ \\
\hline
\end{tabular}

a Allowing for a five-year latency period using lagging.

years in any job. Allowing for no latency period or lagging by 10 or 20 years decreased the apparent associations. Both nasopharyngeal cancers among plywood workers occurred in workers employed for less than five years.

The results for sinonasal cancer for the pooled cohort were primarily due to 10 cases (expected 1.4) that occurred among the British furniture workers. The remaining sinonasal cancer death occurred among white male US furniture workers (expected 0.9). The results from parallel analyses of the British and US furniture workers were inspected for the apparent discrepancy between the results of the two cohorts. While 9 of the 10 sinonasal cancers among the British furniture workers occurred among men first employed prior to 1940, the entrance criterion for the US furniture workers was first employment between 1946 and 1962. The expected number of sinonasal cancers was very small in both groups, but fewer were expected in the US versus the British among workers in the highest probability of exposure category $(0.2$ versus 0.7$)$ and the 30 or more years since first employment category ( 0.1 versus 0.8 ).

No sinonasal cancer deaths were observed among nonfurniture workers, whereas approximately one would have been expected. Of the nine nasopharyngeal cancers, five occurred among the British furniture workers (expected 0.9), two among US furniture workers (expected 1.6), and one each in the NIOSH (expected 0.3) and NCI plywood (expected 0.2) cohorts. The SMR values for multiple myeloma ranged from 1.1 to 2.3 in the individual cohorts. In general, the pooled cohort results were consistent with those of the individual cohorts for common causes of death. For example, the SMR values ranged from 0.7 to 1.0 for all cancers and from 0.8 to 1.0 for lung cancer. The one exception was the previously reported excess of stomach cancer in one cohort (15).

\section{Discussion}

The primary strength of this analysis is the increased power to examine rare causes of death afforded by the pooling of data. In addition, the classification of probability of wood-dust exposure, although crude, represents an improvement over simple summary SMR values for the entire cohort, and only the British furniture worker cohort had previously been examined in this manner. The large numbers also provided the ability to examine trends in the data in relationship to time period of exposure and the number of years since exposure began.

The chief limitation of this analysis was the lack of accurate information regarding exposure to wood dust and other agents. Although it was possible to create some crude exposure indices, misclassification undoubtedly occurred. Within studies, misclassification will have occurred because persons were inaccurately assigned to exposure categories due to the limited exposure information available. Since the exposure information used was obtained prior to the occurrence of disease, the misclassification would be nondifferential and would tend to obscure potential relationships between wood dust and disease and could distort dose-response relationships (26, 27). Further misclassification may have occurred between studies because differences in the detail of the exposure information available could have caused the accuracy of exposure assignment to vary by study. The effects of this type of exposure misclassification are difficult to predict.

Another limitation of this study was the reliance on mortality data as an indicator of disease incidence. Death certificates are a poor source for information regarding nonmalignant respiratory disease and may also lack details on the anatomic subsite of origin and histology information for fatal cancers (28), which are particularly 
important for nasopharynx and sinonasal cancer. In addition, national rates, which were used in all of the analyses, may not accurately reflect the base-line disease risk in this population due to the healthy worker effect (29), social class, and ethnic and regional differences. The pooled cohort had a significantly depressed SMR for total mortality, and therefore the SMR values for some diseases may have been artificially low.

In this study an excess risk of sinonasal cancer was observed among the British furniture workers with the highest wood-dust exposure but not among US furniture workers. It has been noted previously that furniture workers in the United States may not have as high a relative risk of sinonasal cancer as their British counterparts (10, 30). The reasons for this inconsistency are not known, but in this analysis at least part of the discrepancy may have been due to differences in study design and exposure between the two groups. In Britain, the elevated risks were observed among the furniture workers first employed prior to 1940 , while entry into the US cohort began in 1946. The available industrial hygiene measurements would seem to indicate that wood-dust exposures may have been higher in the British industry. However, it is not possible to make a direct comparison because little is known about the workplaces where the US workers were employed, and no measurements are available from earlier periods. It may also be of significance that the British furniture industry in the High Wycombe region produced furniture primarily of hardwood, which has been associated with higher risks of sinonasal cancer than softwoods $(1,7,8)$. No information on species of wood was available for the US furniture workers.

This reanalysis also observed an excess of nasopharyngeal cancer among furniture and plywood workers. Among the furniture workers, a large excess was observed for the men employed in jobs with the greatest likelihood of high wood-dust exposure. We also found an excess of nasopharyngeal cancer for workers holding jobs for which exposure to wood dust was less certain. This observation may be due to a misclassification of exposure, separate effects of different exposures, such as formaldehyde among the plywood workers, or, given the small numbers, chance. Some case-referent studies have reported an association between nasopharyngeal cancer and wood work occupations $(4,31-33)$.

Our analyses suggest that the risk of some of the lymphatic and hematopoietic neoplasms may be elevated among wood workers, particularly multiple myeloma. In the full pooled cohort, the risk of multiple myeloma was greatest among workers with the highest probability of wood-dust exposure, but among furniture workers (who may have had the highest exposures) the trend was less pronounced. Three out of the four multiple myelomas among the plywood workers occurred among persons in the lowest probability of exposure category. From these analyses the specific factors that may be associated with excesses of multiple myeloma among wood workers are unclear, but the overall pattern suggests that both chemical agents and wood dust may play a role. Some studies have found multiple myeloma to be related to chemical exposures that may occur within wood-related industries, such as paints, solvents, and pesticides $(34-37)$. Further assessment of exposures in plywood and other wood-related industries is warranted.

No evidence was found for an excess risk of death due to lung cancer and nonmalignant respiratory disease in any of the stratified analyses, nor were any trends suggestive of a relationship apparent. Among plywood workers, a small excess of bronchitis, emphysema, and asthma was observed, but it did not appear to be associated with any of the surrogate measures of wood dust exposure which were used. An important issue to consider is the respirability of wood dust. The particle size of dust generated by wood-working operations varies somewhat according to the process used and the type and dryness of the wood. Industrial hygiene sampling, however, has generally found the majority of suspended wood dust to have a mass median aerodynamic diameter of greater than $10 \mu \mathrm{m}$, and this is generally above the respirable size $(38,39)$. In this analysis, exposure to finer wood dust would have been expected to occur during furniture and plywood finishing operations. The lack of an excess of disease among workers in these categories could be a true indicator of the absence of effect or could be due to a combination of a poor measurement of exposure to respirable dust or the healthy worker effect. It has been noted that wood workers may smoke less because smoking is prohibited in some workplaces due to the fire hazard posed by wood dust (8). If true, negative confounding by cigarette smoking may be possible. Unfortunately, no data on smoking or other potentially confounding factors were available for this analysis.

In conclusion, this reanalysis of data from five cohorts of workers in wood-related industries confirmed the association between sinonasal cancer and wood-dust exposure; this conclusion is based primarily on the strength of the British furniture worker study. In addition, a similar pattern was observed for nasopharyngeal cancer; this result provides further evidence that it may also be related to wood-dust exposure. Some support for an excess risk of multiple myeloma was also observed. No excesses of lung, larynx, stomach, or colon cancer were found to be associated with any of the surrogate indicators of wood-dust exposure used. Although the studies included in this analysis lacked detailed information on exposures and potential confounders, these limitations and the healthy worker effect would tend to obscure relationships between wood dust and cancer rather than create false positive findings. Large studies with better indicators of exposure are needed to examine the 
relationship between some of the relatively rare cancers found in excess in this study and exposures in woodrelated industries. The use of cancer incidence data, rather than mortality, could also increase study power and allow the examination of the risks associated with specific histological types.

\section{Acknowledgments}

The work reported in this paper was partially undertaken during the tenure of a Research Training Fellowship awarded to Paul Demers by the International Agency for Research on Cancer and was partially funded by a grant of the Commission of the European Union, Directorate General for Employment, Industrial Relations, and Social Affairs.

\section{References}

1. International Agency for Research on Cancer (IARC) Working Group. Wood dust and formaldehyde. Lyon: IARC, 1995. IARC monographs on the evaluation of the carcinogenic risk of chemicals to humans, vol 62 .

2. Acheson ED, Cowdell RH, Hadfield E, Macbeth RG. Nasal cancer in woodworkers in the furniture industry. Br Med $\mathrm{J}$ $1968 ; 2: 587-96$

3. Luce D, Gerin M, Leclerc A, Morcet JF, Brugere J, Goldberg M. Sinonasal cancer and occupational exposure to formaldehyde and other substances. Int J Cancer 1987;53:224-31.

4. Vaughan TL, Davis $S$. Wood dust exposure and squamous cell cancers of the upper respiratory tract. Am J Epidemiol 1991; 133:560-4.

5. Hayes RB, Gerin M, Raatgever JW, de Bruyn A. Woodrelated occupations, wood dust exposure, and sinonasal cancer. Am J Epidemiol 1986;124:569-77.

6. Mohtashamipur E, Norpoth K, Luhmann F. Cancer epidemiology of woodworking. J Cancer Res Clin Oncol 1989;115: $503-15$.

7. Nylander LA, Dement JM. Carcinogenic effects of wood dust: review and discussion. Am J Ind Med 1993;24:619- 47.

8. Acheson ED, Pippard EC, Winter PD. Mortality of English furniture makers. Scand J Work Environ Health 1984;10: 211-7.

9. Rang $\mathrm{EH}$, Acheson $\mathrm{ED}$. Cancer in furniture workers. Int $\mathbf{J}$ Epidemiol 1981;10:253-61.

10. Miller BA, Blair AE, Raynor HL, Sterwart P, Zahm SH, Fraumeni JF. Cancer and other mortality patterns among United States furniture workers. Br J Ind Med 1989;46:508-15.

11. Miller BA, Blair AE, Reed EJ. Extended mortality follow-up among men and women in a US furniture workers union. Am J Ind Med 1994;25:537-49.

12. Robinson C, Fowler D, Brown DP, Lemen RA. Plywood mill workers' mortality patterns 1945-1977. Cincinnati, OH: National Institute for Occupational Safety and Health, 1986. NTIS Publication PB90-147075.

13. Blair A, Stewart PA, Hoover RN. Mortality from lung cancer among workers employed in formaldehyde industries. Am J Ind Med 1990;17:683-99.
14. Blair A, Stewart P, O'Berg M, Gaffey W, Wairath J, Ward J, et al. Mortality among industrial workers exposed to formaldehyde. JNCI 1986;76:1071—84.

15. Roscoe RJ, Steenland K, McCammon CS, Schober SE, Robinson $\mathrm{CF}$, Halperin WE, et al. Colon and stomach mortality among automotive wood model makers. J Occup Med 1992; 34:759-70.

16. Jones PA, Smith LC. Personal exposures to wood dust of woodworkers in the furniture industry in the High Wycombe area: a statistical comparison of 1983 and 1976/77 survey results. Ann Occup Hyg 1986;30:171-84.

17. Hounam RF, Williams $\mathbf{J}$. Levels of airborne dust in furniture making factories in the High Wycombe area. Br J Ind Med 1974;31:1-9.

18. Whitehead LW, Freund T, Hahn LL. Suspended dust concentrations and size distributions, and qualitative analysis of inorganic particles, from wood working operations. Am Ind Hyg Assoc J 1981;42:461-7.

19. Tatken RL, Browning CA. Health effects of exposure to wood dust: a summary of the literature. Cincinnati, OH: National Institute for Occupational Safety and Health, 1987.

20. Edwards JJ, Brooks SM, Henderson FI, Apol AG. Health hazard evaluation report: Weyerhaeuser Company, Longview, Washington. Cincinnati, OH: National Institute for Occupational Safety and Health, 1978. NTIS, no PB81- 144081.

21. McCammon CS, Robinson C, Waxweiler RJ, Roscoe R. Industrial hygiene characterization of automotive wood model shops. Am Ind Hyg Assoc J 1985;46:343-9.

22. Breslow NE, Day NE. Statistical methods in cancer research; vol II (The design and analysis of cohort studies). Lyon: International Agency for Research on Cancer, 1987.

23. Coleman MP, Douglas A, Hermon C, Peto J. Cohort study analysis with a FORTRAN computer program. Int J Epidemiol 1986;15:134-7.

24. Steenland K, Beaumont JJ, Spaeth S, Brown D, Okun A, Jurcenko $\mathrm{L}$, et al. New developements in the life table analysis system of the National Institute for Occupational Safety and health. J Occup Med 1990;32:1091-8.

25. Checkoway H, Pearce N, Hickey JL, Dement JM. Latency analysis in occupational epidemiology. Arch Environ Health 1990;45:95-100.

26. Birkett NJ. Effect of non-differential misclassification on estimates of odds ratios with multiple levels of exposure. Am J Epidemiol 1992;136:356-62.

27. Copeland KT, Chechoway H, McMichael AJ, Holbrook RH. Bias due to misclassification in the estimate of relative risk. Am J Epidemiol 1977;105:488-95.

28. Percy CL, Miller BA, Gloeckler LA. Effect of changes in cancer classification and the accuracy of cancer death certificates on trends in cancer mortality. Ann NY Acad Sci 1990; 609:87-97.

29. Fox AJ, Collier PF. Low mortality rates in industrial cohort studies due to selection for work and survival in industry. $\mathrm{Br} J$ Prev Soc Med 1976;30:225-30.

30. Brinton LA, Blot WJ, Becker JA, Winn DM, Browder JP, Farmer JC, et al. A case-control study of cancers of the nasal cavity and paranasal sinuses. Am J Epidemiol 1984;1 19:896906.

31. Hardell L, Johansson B, Axelson O. Epidemiological study of nasal and nasopharyngeal cancer and their relation to phenoxy acid or chlorophenol exposure. Am J Ind Med 1982;3:24757.

32. Kawachi I, Pearce N, Fraser J. A New Zealand Cancer Registry-based study of cancer in wood workers. Cancer 
1989;64:2609-13.

33. Sriamporn $S$, Vatanasapt V, Pisani $P$, Yongchaiyudha $S$, Rungpitarangsri V. Environmental risk factors for nasopharyngeal carcinoma: a case-control study in northeastern Thailand. Cancer Epidemiol Biomarkers Prev 1992;1:345-8.

34. Blair A, Hoar Zahm S. Cancer among farmers. Philadelphia, PA: Hanley \& Belfus Inc, 1991:335-54. Occupational medicine: state of the art reviews, vol 6 no 3 .

35. Boffetta P, Stellman SD, Garfinkel L. A case-control study of multiple myeloma nested in the American Cancer Society prospective study. Int J Cancer 1989;43:554-9.

36. Lundberg I. Mortality and cancer incidence among Swedish paint industry workers with long term exposure to organic solvents. Scand J Work Environ Health 1986;12:108-13.

37. Morris PD, Koepsel TD, Daling JR, Taylor JW, Lyon JL, Swanson GM, et al. Toxic substance exposure and multiple myeloma: a case-control study. JNCI 1986;76:987—94

38. Hinds WC. Basis for particle size-selective sampling for wood dust. Appl Ind Hyg 1988;3:67-72.

39. Phalen RF, Hinds WC, John W, Lioy PJ, Lippman M, McCawley MA, et al. Rationale and recommendations for particle size selective sampling in the workplace. Appl Ind Hyg 1988;1:3-14.

40. Demers PA, Boffetta P, Kogevinas M, Battista G, Belli S Blair A, et al. Pooled analysis of epidemiologic studies of wood dust and cancer: a technical report of the International Agency for Research on Cancer. Lyon: International Agency of Research on Cander. In press.

Received for publication: 2 May 1994 